\title{
AN ENERGY AUDIT IN A TEA MANUFACTURING INDUSTRY AT NORTH BENGAL, INDIA
}

\author{
Soupayan Mitra ${ }^{1}$, Totan Roy ${ }^{2}$ \\ ${ }^{1}$ Associate Professor, Mechanical Engineering Department, Jalpaiguri Government Engineering College, Jalpaiguri- \\ 735102, West Bengal, India \\ ${ }^{2}$ Post Graduate Scholar, Mechanical Engineering Department, Jalpaiguri Government Engineering College, \\ Jalpaiguri- 735102, West Bengal, India
}

\begin{abstract}
Growing concerns about rising energy bills due to high energy consumption and its adverse environmental impacts vis-à-vis stringent environment protection act (EPA) has forced many industries to carry out energy audit. The energy audit helps identify the opportunities to reduce energy bills keeping production amount and quality same or, even better and thereby, conserve environment. In the present paper focus is given on energy audit plan for a medium scale tea manufacturing industry having its own garden located at Jalpaiguri area of North Bengal, which is the northern part of West Bengal, India. By executing the audit, amount of energy usage by the machineries and production processes are determined and analyzed. Finally somesuitable recommendations are suggested to bring down overall energy use.
\end{abstract}

Keywords: Energy Audit; Energy Management; Tea Manufacturing Industry ****

\section{INTRODUCTION}

The essence of energy audit following Energy Conservation Act (EC Act)-2001 [1][2] is to monitor and analysis of the energy use in any industry or, organization and thereafter, submission of exhaustive report highlighting opportunities to improve energy efficiency and cut down energy consumption along with cost benefit calculations and action plan to achieve the purpose of energy usage reduction and environment protection.

The need of proper energy management vis-à-vis energy audit is becoming a must for any moderate to high energy consuming industry including tea manufacturing factory due to ever increasing energy cost and stringent environment protection law. Proper implementation of energy audit helps cut short energy bill and improve working environment by arresting smoke, dust, steam, hot air leakages etc.through suitable methodologies without affecting and,in fact, sometimes improving amount and quality of production.

India is the largest tea producing country in the world. India has acquired an exalted status on the global tea map. India produces all types of tea i.e., CTC(crush, tear and curl) tea, Orthodox tea, green tea and organic tea. Out of the above, CTC and orthodox are the most common.

In this present paper thorough energy audit is carried out for a medium size tea garden (total area 940 hectares) factory located at Jalpaiguri area of North Bengal, India and various energy conservation methodologies are proposed through this audit which if implemented will definitely reduce energy bills and conserve environment.

\section{WORKING PROCEDURE OF ENERGY}

\section{AUDIT}

Energy audit identifies energy usage at every energy-costcentre i.e., in all machineries, processes and others which consumes energy in one form or, other and analyze them in order to find out procedures to cut short the energy cost.

Depending on the type of industry/organization and the depth of energy audit need, in terms of cost reduction and other aspects, the energy audit may be classified as Preliminary, Targeted and Detailed audits. [2][3][4]. Detailed energy audit is the most comprehensive audit which includes three phases viz. pre-audit, audit and postaudit phases. In this present study the energy audit carried out is a detailed audit.

\section{PROGRESS OF DETAILED ENERGY AUDIT WORK}

\subsection{The 1st Phase I.E. Pre-Audit Phase}

In this phase initially the whole tea manufacturing factory is inspected for understanding the production machineries and processes, ratings of machines and possible area of energy wastages are noted. A discussion with factory manager and operation staff is organized to take stock of the overall situation and to explain them the purpose of energy audit and its advantages and their co-operation is sought. [2,4] 


\subsubsection{Factory Details}

Table 1: Details about Tea Manufacturing Factory

\begin{tabular}{|l|l|}
\hline Name & $\begin{array}{l}\text { Jalpaiguri Tea Garden (not } \\
\text { original name) }\end{array}$ \\
\hline Power Sources & i) $\begin{array}{l}\text { Grid Power Supply } \\
\text { (WBSEDCL) }\end{array}$ \\
ii) $\begin{array}{l}\text { Own Generation (used when } \\
\text { Grid power is not available) }\end{array}$ \\
\hline $\begin{array}{l}\text { Heat Generating } \\
\text { Source }\end{array}$ & $\begin{array}{l}\text { Coal(used in Coal Firedfurnace to } \\
\text { heat up air) }\end{array}$ \\
\hline $\begin{array}{l}\text { Overall Production } \\
\text { in a Year }\end{array}$ & 1350000 kg(approx.) of CTC tea \\
\hline $\begin{array}{l}\text { Factory working } \\
\text { Time }\end{array}$ & 18 hours in a day \\
\hline
\end{tabular}

\subsubsection{Factory Layout:}

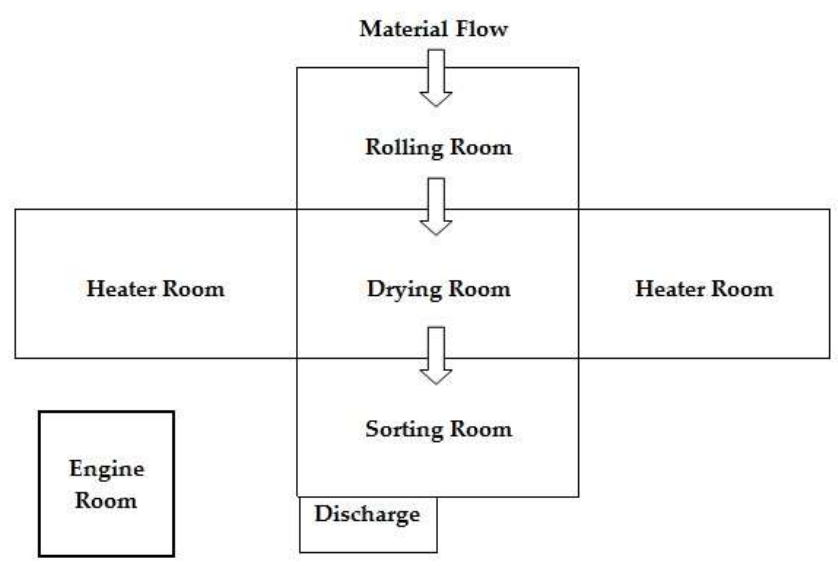

Figure 1: Factory Layout

\subsubsection{Tea Manufacturing Process Study:}

All the processes involved in tea production system are meticulously observed and following is a description of the processes:

Tea Handling: The Plucker pluck the green leaves from the garden. There is a special technique of plucking which is followed by the pluckers.

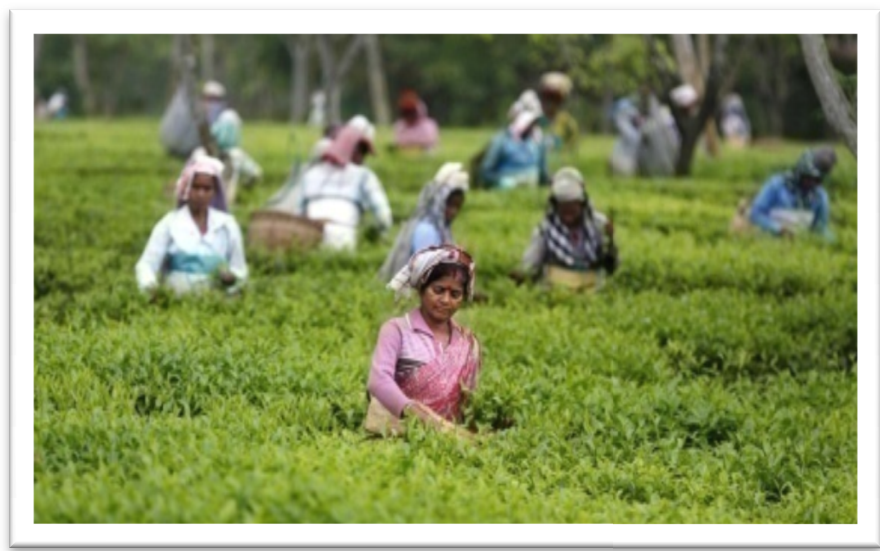

Figure 2: Tea Plucking
Withering : Withering is one of the most important stage of tea manufacturing. In the withering process removal of moisture from the green leaves are carried out. Green leaves are kept approximatelyfor 12 to 14 hours as per requirement on the Trough, which is a metal net. Axial flow fans are used at one end to blow air beneath the trough and the air comes out through the green leaves and thus removes moisture from the leaves.

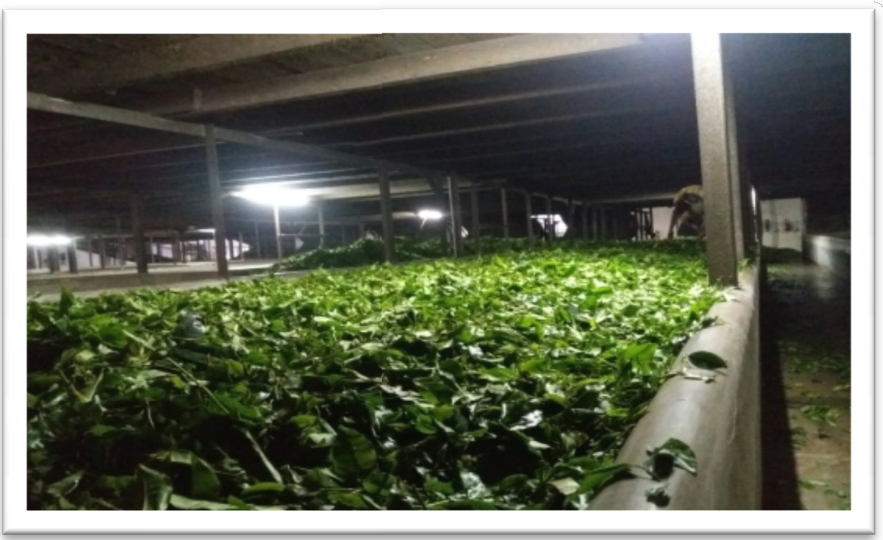

Figure 3: Withering

CTC (Crush, Tear \& Curl) process: This CTC process is done by the C.T.C Machine. In C.T.C. machine the three processes namely, crush, tear \& curl,on the tea leaves are done by using suitable high and low speed rollers. The green leaves after being withered is sent to the Feeder with the monorail and fall down in the Rotor Vane at the rate of $500 \mathrm{~kg} /$ hour. This is the first part of the C.T.C. Machine. After that green leaves are passed through belt conveyors and in the conveyors itself there are sets of rollers having different speeds at different locations of the conveyor belt which finally carry out the remaining CTC operations.

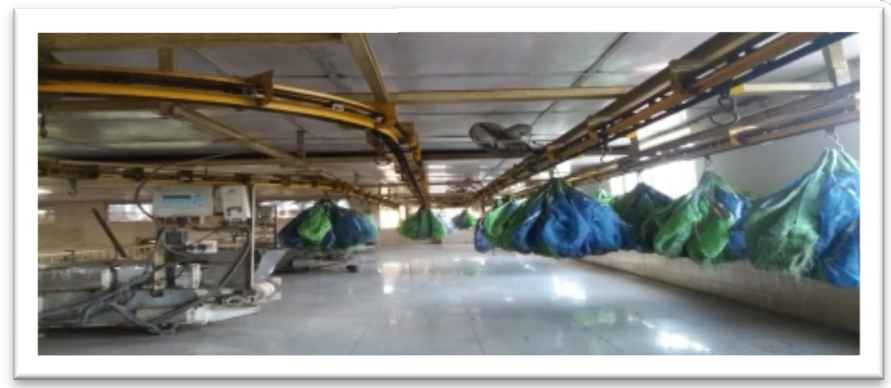

Figure 4: Tea Handling by Monorail

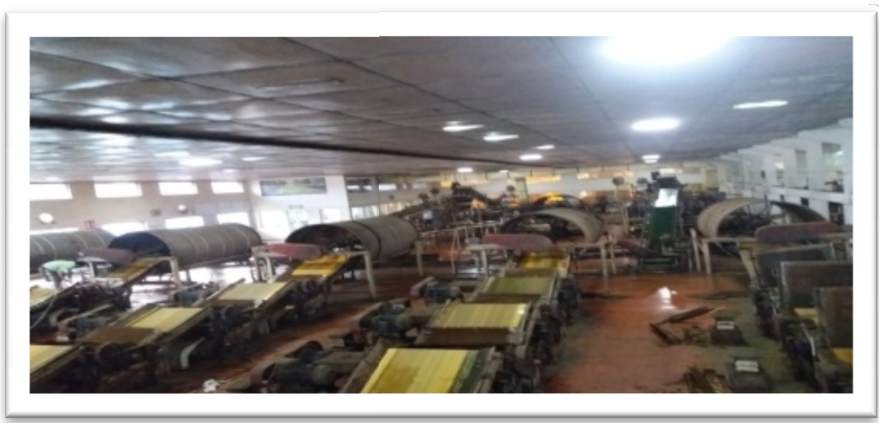

Figure 5: CTC Machine 
Fermentation : After processing in CTC machine tea materials are sent to CFM (Continuous Fermenting Machine)which is basically a belt conveyor. Fermentation is an important stageofBlack tea manufacturing. During fermentation a large number of dissimilar chemical reactions take place by using polyphenol and oxidation with atmospheric oxygen.In this process the chlorophyll in the tea leaf is enzymatically broken down, and its tannins are released or transformed. At the end of fermenting, the tea materialspass through a special kind of spiral type device located on the conveyor itself, called 'santoor', which makes the tea materials in a desiredsmall round shape conventionally named as "gooli". Bigger "goolis" are send to a mini C.T.C. for reprocessing .

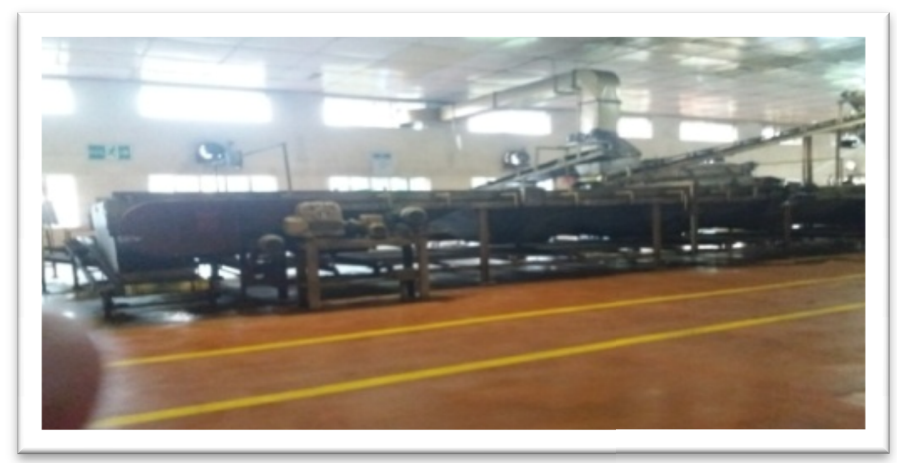

Figure 6: Fermentation Process in CFM

Drying: In this process tea materials are dried up after fermentation. In the present factory, hot air from coal fired air heater dry up the tea materials in three numbers of Vibro Fluid Bed Dryers(VFBD). This VFBD comprises of heater shell and accessories supported by suitable ducting, hot air blower,temparature controller and feed system.After the drying process all the tea materials pass through conveyorstothe Weight Measuring Unit.

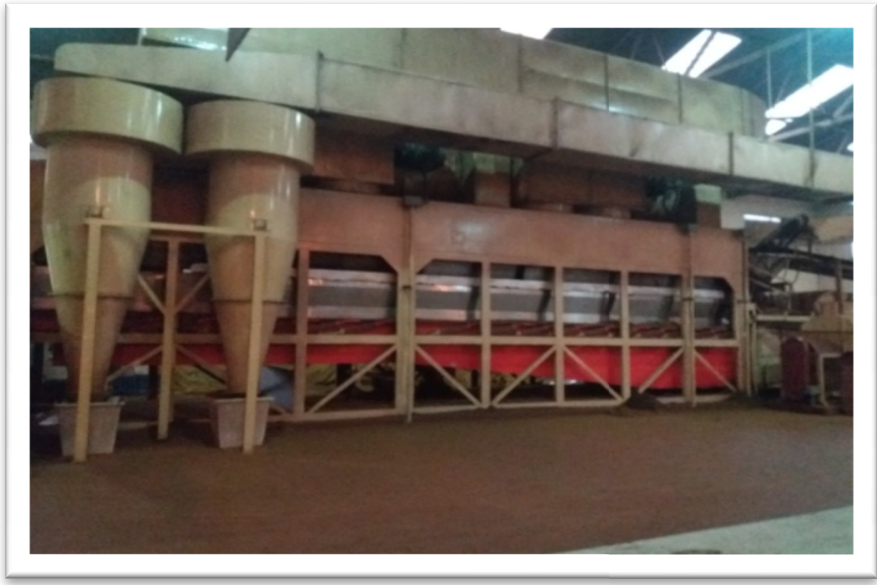

Figure 7: Vibro Fluid Bed Dryer (VFBD)

Weight Mesuring Unit: A Dryer Mouth Batch Weighting Machine is used to measure the tea grains weight. This weight is compared with the weight of green tea leaves measured just before the C.T.C. machine. From this comparison, the quality of 'drying' which, in turn, indicates the quality of produced tea is ascertained.

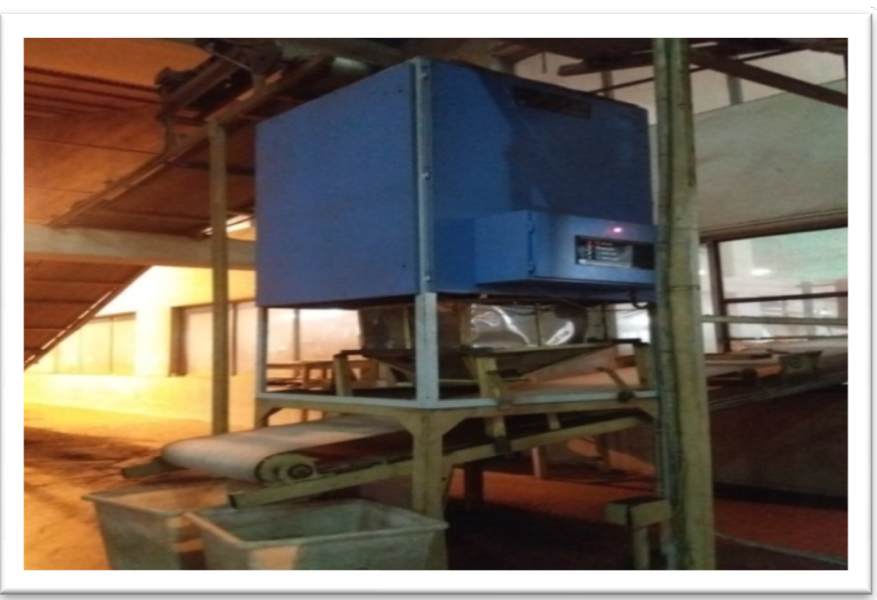

Figure 8: Batch Weighting Machine

Sorting: After the tea is measured in the above weighting machine, it is sent to big stroage Hoppers, two in numbers. At the end part of the each hopper, there are six numbers of Vibro Screens having different sizes of mesh, starting from thebiggest size mesh screen at the top. Theses screens vibrate and segregrate tea materials based on its grain size into six different categories or, grades. The market price of tea varies from grade to grade.

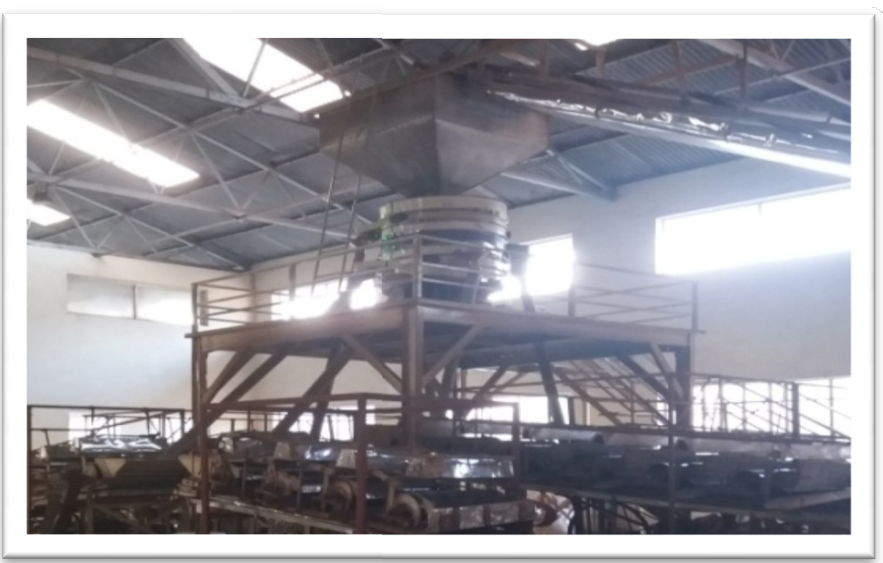

Figure 9: Vibro Screen Sorter

After Sorting : Graded teas fall into small hoopers and pass through Vibro Slow Speed Fibre Extractor machine which extracts fibre,flaky and unwanted debris from the graded tea.

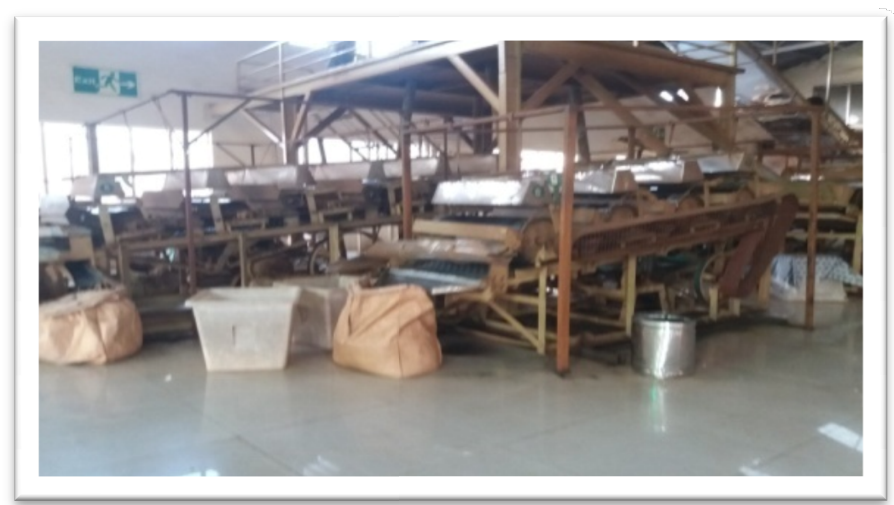

Figure 10: Vibro Slow Speed Fiber Extractor 
Packaging and Delivary: After separating all different graded or, quality tea, packaging is done in plastic/paper bags and despatched from the factory.
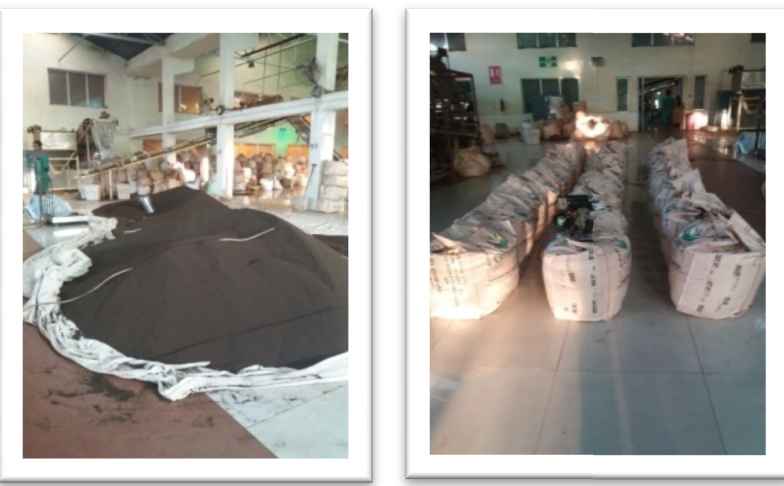

Figure 11: i) Tea Storing ii) Packaging

\subsection{Audit Phase- II}

During audit phase II the following observations and analysis are completed.

Table 2Analysis of Tea Production

\begin{tabular}{|l|l|l|l|l|l|l|l|}
\hline & \multicolumn{2}{|l|}{ Treen leaf Quantity (kg) quantity (kg) } & \multicolumn{2}{l|}{$\begin{array}{l}\text { Ratio } \\
\text { (Tea/Green Leaf) }\end{array}$} \\
\hline Month & \multicolumn{5}{|l|}{ Tear } \\
\hline & $\mathbf{2 0 1 4}$ & $\mathbf{2 0 1 5}$ & $\mathbf{2 0 1 4}$ & $\mathbf{2 0 1 5}$ & $\mathbf{2 0 1 4}$ & $\mathbf{2 0 1 5}$ \\
\hline January & 21079 & 12094 & 5100 & 2830 & 0.242 & 0.234 \\
\hline February & 63635 & 97218 & 14290 & 22870 & 0.224 & 0.235 \\
\hline March & 595393 & 451118 & 134408 & 103556 & 0.225 & 0.229 \\
\hline April & 338964 & 516770 & 85444 & 124659 & 0.252 & 0.241 \\
\hline May & 743822 & 1031868 & 170944 & 235052 & 0.229 & 0.227 \\
\hline June & 1467553 & 1427472 & 321064 & 308657 & 0.218 & 0.216 \\
\hline July & 1713719 & 1314227 & 368964 & 287160 & 0.215 & 0.218 \\
\hline August & 1626001 & 1395765 & 350266 & 302853 & 0.215 & 0.216 \\
\hline September & 1639666 & 1478685 & 354500 & 318362 & 0.216 & 0.215 \\
\hline October & 1545789 & 1663999 & 343195 & 372895 & 0.222 & 0.224 \\
\hline November & 1343319 & 1297715 & 305562 & 299950 & 0.227 & 0.231 \\
\hline December & 847454 & 461256 & 228989 & 153650 & 0.270 & 0.333 \\
\hline
\end{tabular}

Table 3: Summary of Annual Electrical Energy Consumption

\begin{tabular}{|l|l|l|l|l|l|l|}
\hline & \multicolumn{3}{|l|}{$\begin{array}{l}\text { Grid Supply Electrical } \\
\text { Energy (KWh) } \\
\text { Consumption }\end{array}$} & $\begin{array}{l}\text { Diesel Engine Generated } \\
\text { Electrical Energy (KWh) } \\
\text { Consumption }\end{array}$ & $\begin{array}{l}\text { Total Electrical } \\
\text { Energy (KWh) } \\
\text { Consumption }\end{array}$ \\
\hline Month & \multicolumn{5}{|l|}{ Year } \\
\hline & $\mathbf{2 0 1 4}$ & $\mathbf{2 0 1 5}$ & $\mathbf{2 0 1 4}$ & $\mathbf{2 0 1 5}$ & $\mathbf{2 0 1 4}$ & $\mathbf{2 0 1 5}$ \\
\hline January & 2928 & 1331 & 64 & 40 & 2992 & 1371 \\
\hline February & 3422 & 5704 & 144 & 768 & 3566 & 6472 \\
\hline March & 54187 & 46857 & 400 & 1800 & 54587 & 48657 \\
\hline April & 35743 & 46002 & 3312 & 5520 & 39055 & 51522 \\
\hline May & 79928 & 96019 & 8872 & 25016 & 88800 & 121035 \\
\hline June & 202859 & 190281 & 20736 & 33552 & 223595 & 223833 \\
\hline July & 296489 & 160344 & 9808 & 27232 & 306297 & 187576 \\
\hline August & 319830 & 182955 & 11064 & 17280 & 330894 & 200235 \\
\hline September & 225111 & 199709 & 9632 & 6416 & 234743 & 206125 \\
\hline October & 231675 & 281079 & 4144 & 11672 & 235819 & 292751 \\
\hline November & 137482 & 190372 & 2416 & 5272 & 139898 & 195644 \\
\hline December & 158836 & 73509 & 2896 & 3128 & 161732 & 76637 \\
\hline
\end{tabular}




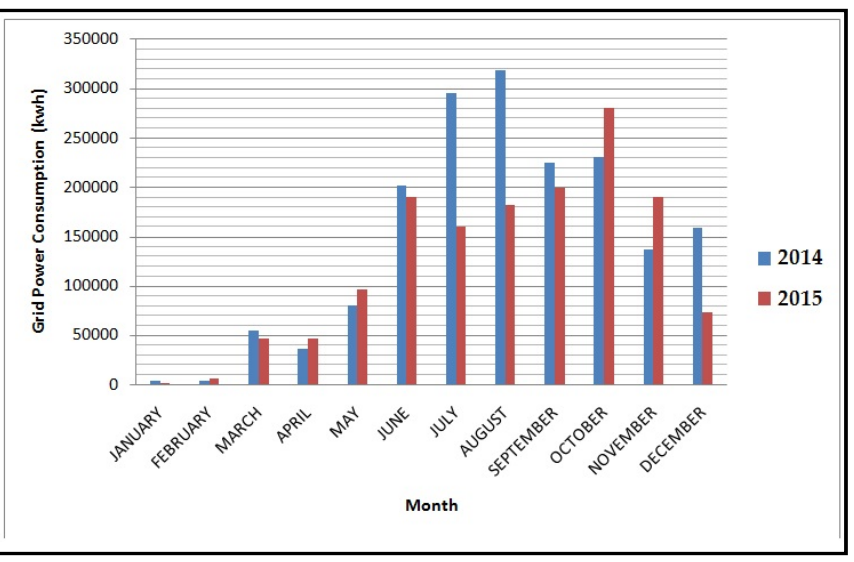

Figure 12: Month wise Grid Power Consumption(KWh)

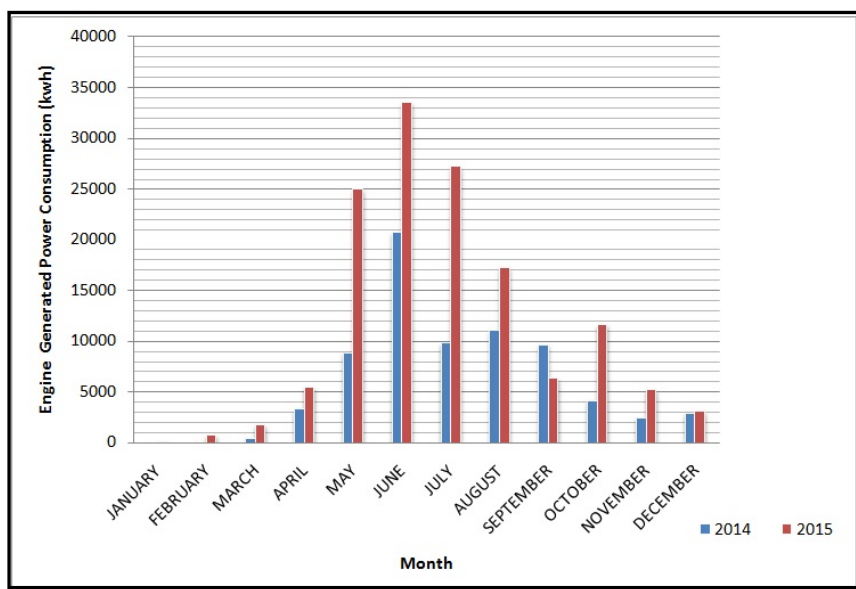

Figure 13: Month wise Engine Generated Electrical Power Consumption (KWh)

Table 4: Tea Production wise Energy Consumption Analysis

\begin{tabular}{|l|l|l|l|l|l|l|}
\hline & \multicolumn{5}{|l|}{ Tea quantity (kg) } & \multicolumn{3}{l}{$\begin{array}{l}\text { Total Electrical } \\
\text { Energy Consumption in KWh }\end{array}$} & $\begin{array}{l}\text { Electrical Energy } \\
\text { Consumption per kg of tea } \\
\text { (kwh/kg) }\end{array}$ \\
\hline Month & \multicolumn{5}{|l|}{ Year } \\
\hline & $\mathbf{2 0 1 4}$ & $\mathbf{2 0 1 5}$ & $\mathbf{2 0 1 4}$ & $\mathbf{2 0 1 5}$ & $\mathbf{2 0 1 4}$ & $\mathbf{2 0 1 5}$ \\
\hline January & 5100 & 2830 & 2992 & 1371 & 0.5866 & 0.4844 \\
\hline February & 14290 & 22870 & 3566 & 6472 & 0.2495 & 0.2829 \\
\hline March & 134408 & 103556 & 54587 & 48657 & 0.4061 & 0.4698 \\
\hline April & 85444 & 124659 & 39055 & 51522 & 0.4570 & 0.4133 \\
\hline May & 170944 & 235052 & 88800 & 121035 & 0.5194 & 0.5149 \\
\hline June & 321064 & 308657 & 223595 & 223833 & 0.6964 & 0.7251 \\
\hline July & 368964 & 287160 & 306297 & 187576 & 0.8301 & 0.6532 \\
\hline August & 350266 & 302853 & 330894 & 200235 & 0.9446 & 0.6611 \\
\hline September & 354500 & 318362 & 234743 & 206125 & 0.6621 & 0.6474 \\
\hline October & 343195 & 372895 & 235819 & 292751 & 0.6871 & 0.7850 \\
\hline November & 305562 & 299950 & 139898 & 195644 & 0.4578 & 0.6522 \\
\hline December & 228989 & 153650 & 161732 & 76637 & 0.7062 & 0.4987 \\
\hline
\end{tabular}

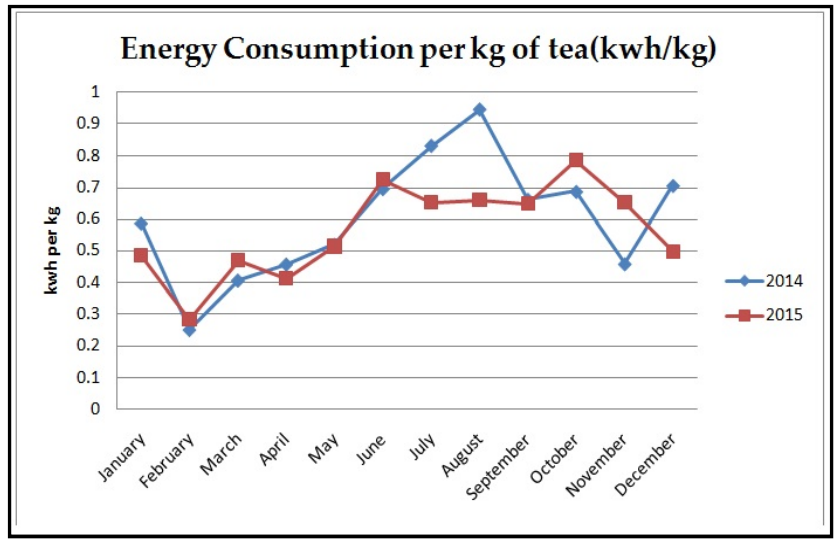

Figure 14: Rate of Electrical Energy Consumption per unit Tea Production $(\mathrm{KWh} / \mathrm{kg})$
Table 5: Overall Yearly Data

\begin{tabular}{|l|l|l|}
\hline & $\mathbf{2 0 1 4}$ & $\mathbf{2 0 1 5}$ \\
\hline $\begin{array}{l}\text { Total Tea Production } \\
\text { (kg) }\end{array}$ & 2682726 & 2532494 \\
\hline $\begin{array}{l}\text { Total Electrical Power } \\
\text { Consumption (KWh) }\end{array}$ & 1821978 & 1611858 \\
\hline $\begin{array}{l}\text { Total Coal Consumption } \\
\text { in furnace to heat up air } \\
\text { (kg) }\end{array}$ & 2339582 & 2103746 \\
\hline
\end{tabular}




\section{POST-AUDIT :}

\subsection{Audit Phase-III : Proposals To Reduce Energy} Consumption In Tea Production Processes
Present manufacturing processes for tea production in the Tea factory are meticulously observed and following are the possible improvement proposals for different processes to reduce energy cost and also for better operation of the plant.

Table 6: Process Withering

\begin{tabular}{|l|l|}
\hline $\begin{array}{l}\text { Present Practice/ problem related to present } \\
\text { technology }\end{array}$ & $\begin{array}{l}\text { Solution for Technology Gap/problem related to present } \\
\text { practice }\end{array}$ \\
\hline $\begin{array}{l}\text { In the factory the withering fans run continuously } \\
\text { during withering process and intermittent running of } \\
\text { fans is not practiced. }\end{array}$ & $\begin{array}{l}\text { Intermittent withering instead of continuous withering as } \\
\text { practiced by some of the gardens without loss in withering time } \\
\text { and quality of product. }\end{array}$ \\
\hline $\begin{array}{l}\text { Present factory like most of other factories are having } \\
\text { aluminum/steel fan blades in withering fans. }\end{array}$ & Use of energy efficient FRP(fiber reinforced plastics) blades. \\
\hline $\begin{array}{l}\text { Air leakage was observed from dampers and side } \\
\text { windows. }\end{array}$ & $\begin{array}{l}\text { Arresting air leakage can save up to 10-15\% of total flow } \\
\text { volume produced by fans which is otherwise wasted as leakage. }\end{array}$ \\
\hline
\end{tabular}

Table 7: Process: CTC (Cutting, Twisting and Curling)

\begin{tabular}{|l|l|}
\hline $\begin{array}{l}\text { Present Practice/problem related to present } \\
\text { technology }\end{array}$ & $\begin{array}{l}\text { Solution for Technology Gap/problem related to present } \\
\text { practice }\end{array}$ \\
\hline $\begin{array}{l}\text { There are eight conveyor-banks, known as CTC } \\
\text { banks. During off peak season C.T.C. machines are } \\
\text { lightly loaded but still most of the banks of CTCs are } \\
\text { operated due to typical arrangements of the banks. }\end{array}$ & $\begin{array}{l}\text { Energy cost will be reduced by duly modified arrangement, use of } \\
\text { single CTC cutter, known as rotor-vane, during off peak season } \\
\text { can be practiced with a single conveyer-bank to distribute the } \\
\text { shred leaves equally to only required nos. of CTC banks. }\end{array}$ \\
\hline $\begin{array}{l}\text { Most of the CTC motors are under loaded as the } \\
\text { rating of the motors seem to be on the higher size } \\
\text { considering production volume }\end{array}$ & $\begin{array}{l}\text { Proper sizing of CTC motors.( may be a single motor, along with } \\
\text { a back-up machine, having higher rating instead of three motors } \\
\text { can be tried) }\end{array}$ \\
\hline
\end{tabular}

Table 8: Process Fermentation

\begin{tabular}{|l|l|}
\hline $\begin{array}{l}\text { Present Practice/problem related to present } \\
\text { technology }\end{array}$ & $\begin{array}{l}\text { Solution for Technology Gap/problem related to } \\
\text { present practice }\end{array}$ \\
\hline $\begin{array}{l}\text { In CFM (continuous fermentation machine) air leakage was } \\
\text { observed from unloaded banks. }\end{array}$ & $\begin{array}{l}\text { Stopping air leakage in CFM by dampers and use of } \\
\text { VFD through sensors. }\end{array}$ \\
\hline $\begin{array}{l}\text { Air humidifier in case of floor fermentation is operated } \\
\text { continuously without any regulator. }\end{array}$ & $\begin{array}{l}\text { Regulating the humidifier as per the requirement in } \\
\text { floor fermentation. }\end{array}$ \\
\hline $\begin{array}{l}\text { Undesired bigger size ball formation up to 5-6\% of the total made } \\
\text { tea is observed at drier mouth. These balls are sent back to a mini } \\
\text { C.T.C machine and reprocessed again resulting in loss of energy } \\
\text { and manpower in reprocessing. }\end{array}$ & $\begin{array}{l}\text { Use of ball breaker after fermentation to reduce ball } \\
\text { formation. }\end{array}$ \\
\hline
\end{tabular}

Table 9: Process Drying

\begin{tabular}{|l|l|}
\hline $\begin{array}{l}\text { Present Practice/problem related to present } \\
\text { technology }\end{array}$ & $\begin{array}{l}\text { Solution for Technology Gap/problem related to present } \\
\text { practice }\end{array}$ \\
\hline $\begin{array}{l}\text { Hot air leakage is observed from hot air carrying ducts } \\
\text { at isolating dampers and joints and insulation of hot air } \\
\text { ducts are not proper. }\end{array}$ & $\begin{array}{l}\text { Stopping hot air leakage by proper sealing of dampers and } \\
\text { providing proper insulation to ducts to reduce energy loss. }\end{array}$ \\
\hline $\begin{array}{l}\text { Hot air exhaust from drier (at 80-90 deg C) is vented } \\
\text { out. Potential of heat recovery of low grade heat not } \\
\text { explored. }\end{array}$ & $\begin{array}{l}\text { Employment of proper mechanism for re-circulation of exhaust } \\
\text { hot air for pre-heating inlet air. } \\
\text { Also use of exhaust air for hot water generation can be explored. }\end{array}$ \\
\hline $\begin{array}{l}\text { Excess air in coal fired air heater is not regulated. High } \\
\text { percentage of excess air results in lower performance } \\
\text { of heaters. }\end{array}$ & $\begin{array}{l}\text { Use of proper quantity of air required for tea drying process by } \\
\text { Automatic air-flow controller (AAFC) will reduce coalcost. }\end{array}$ \\
\hline $\begin{array}{l}\text { Regular cleaning of tubes and ducts in coal fired air } \\
\text { heaters are not done, thick formation of carbon layer } \\
\text { observed. }\end{array}$ & $\begin{array}{l}\text { Regular cleaning of tubes and ducts to improve heat transfer } \\
\text { efficiency and thereby reduction in coal consumption. }\end{array}$ \\
\hline $\begin{array}{l}\text { Flue gas directly vented out through chimney without } \\
\text { any heat recovery in coal fired furnace. }\end{array}$ & Preheating the coal furnace inlet air by outgoing flue gas. \\
\hline
\end{tabular}

\section{CONCLUSION}


Successful implementation of energy audit reveals a number of opportunities to reduce energy cost, enhance effectiveness and quality in production and preserve environment degradation. In this present work, complete energy audit is carried out for a medium sized tea manufacturing factory located at Jalpaiguri, West Bengal. At first the purposes, methodology and types of energy audits are described. To carry out the energy audit starting from the complete walk-through visit, detail understanding of all the tea production processes including study of all the machines involved in the processes and their energy consumption patterns and overall arrangement of the machines, conveyor systems, ducting etc. are done and noted. Electricity and coal consumption for the years 2014 and 2015 along with tea production volume are collected and analyzed along with cost involvement. Possible avenues to reduce energy cost in the production system and for other areas like air loss etc. are proposed in detail. It is expected that once these recommendation are successfully implemented, energy cost in tea production will be reduced by substantial amount, which not only make the company more competitive in the market but also reduce environment pollution.

\section{REFERENCE}

[1]. Energy Conservation Act (EC Act)- 2001, Published in the "The Gazette of India (extraordinary),no.- 60, Registered no. DL-33004/2001, dated : 01/10/2001"; www.powermin.nic.in

[2]. BEE-Bureau of Energy Efficiency, https://www.bee.gov.in

[3]. "Working Manual on Energy Auditing", Asian Productivity Organization, (2008)

[4]. "Energy audit manual and reports", NPC (National Productivity Council); www.npcindia.gov.in

\section{BIOGRAPHIES}

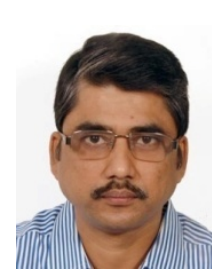

Dr. Soupayan Mitra (B.E, M.M.E, and $\mathrm{PhD})$ is an Associate Professor in Mechanical Engineering Department of Jalpaiguri Govt. Engineering College of West Bengal, India. During his 18 years of service as Engineering faculty, he has published about 25 nos. of papers and guided a nos. of M.Tech, students and two PhD scholars. His field of interest is renewable energy, energy management and thermal engineering.

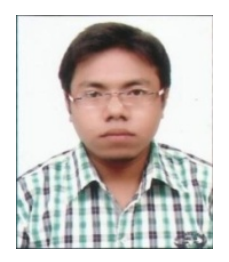

Totan Roy, B.Tech (Mechanical Engineering) from West Bengal University of Technology, Post Graduate Scholar, M.Tech (Production Technology and Management) from Jalpaiguri Government Engineering College. 